\title{
IMPROVING EFFICIENCY AND EFFECTIVENESS OF CONSULTATION PROCESS BETWEEN LECTURERS AND STUDENTS THROUGH AN INFORMATION SYSTEM SOFTWARE BASED INTRANET
}

\author{
Susana Limanto and Ellysa Tjandra \\ Informatics Engineering Department, Faculty of Engineering, Universitas Surabaya, Jl. Raya \\ Kalirungkut, Surabaya, 60293, Indonesia \\ E-mail: susana@ubaya.ac.id
}

\begin{abstract}
Students need to consult their problem such as final projects, academic problem, or personal problems to their lecturers. This consultation's processes are helped by administrative staffs that make the processes relatively slow due to the high workload of the staffs. Therefore, this research tries to address this problem by creating intranet based information system to reduce the role of administrative staffs. This system provide several features such as schedule the regular consultation by lecturers, schedule the addition consultation by lecturers, cancel a scheduled consultations, change the schedule of consultations by lecturers, register for consultation by students, record the implementation consulting by lecturers, and reports. The consultation software was implemented at Informatics Engineering department, University ' $\mathrm{X}$ ' for one month. After one month, a test was conducted involving five lecturers and twenty students. Testing result showed that the consultation process becomes more efficient, effective and satisfying.
\end{abstract}

Keywords: appointments, consultation, information system, intranet

\begin{abstract}
Abstrak
Mahasiswa perlu berkonsultasi mengenai masalah mereka seperti tugas akhir, masalah akademik, atau masalah pribadi kepada dosen mereka. Proses konsultasi ini dibantu oleh staf administrasi yang membuat proses relatif lambat karena beban kerja yang tinggi dari staf. Oleh karena itu, penelitian ini mencoba untuk mengatasi masalah ini dengan menciptakan sistem informasi berbasis intranet untuk mengurangi peran staf administrasi. Sistem ini menyediakan beberapa fitur seperti menjadwalkan konsultasi rutin oleh dosen, jadwal konsultasi Selain oleh dosen, membatalkan konsultasi dijadwalkan, mengubah jadwal konsultasi dengan dosen, mendaftar untuk konsultasi oleh siswa, merekam pelaksanaan konsultasi dengan dosen, dan laporan. Perangkat lunak konsultasi diterapkan di departemen Teknik Informatika, Universitas ' $X$ ' selama satu bulan. Setelah satu bulan, tes dilakukan melibatkan lima dosen dan dua puluh siswa. Hasil pengujian menunjukkan bahwa proses konsultasi menjadi lebih efisien, efektif dan memuaskan.
\end{abstract}

Kata Kunci: intranet, konsultasi, pertemuan, sistem informasi

\section{Introduction}

One of the lecturers' responsibilities instead of teaching is providing consultation schedule for the students who need their help. There are three types of consultations which are offered in Informatics Engineering Department of University ' $\mathrm{X}$ ', they are: academic consultation, final project consultation, and personal consultation. Academic consultation is offered to help the students who have academic problems, such as difficulty in understanding courses materials, study plan, etc. Final project consultation is aimed to guide students finishing their final project, while personal consultation is offered to help students who have private problems such as counseling.

For this purpose, all lecturers in Informatics Engineering Department of University ' $\mathrm{X}$ ' should set their consultation schedules in the beginning of each semester. A student could only attend a consultation by appointments via administrative staff. The staff would check the lecturer' schedule to make sure that there was no overlapping appointments and then recorded the appointments data in an appointments book, informed the lecturer, wait for the lecturer's approval, and finally informed the student and set the queue number for the student. This process took a long time and inefficient. The other problem is when consultation was being attended. While waiting 
their turns, students must wait in a student lounge which being located separately from the lecturers' room. Lecturers must be out of the room to call a student who had a turn. This process consumed more time and effort so it was needed revamping the system so that consultation process become more efficient.

\section{Methodology}

System is defined as a group of mutually related, cooperating elements working on reaching a common goal by taking inputs and producing outputs in organized transformation processes [1]. The elements of a system can be different from the other systems. However, all systems must have three main elements as shown in Figure 1. Data as input is absolutely required by the system to produce information as output. Information is defined as a result of processing data by a system, which has meaning and benefit to the receiver. The relationship between data and information can be seen in Figure 2.

A data Flow Diagram (DFD) is a graphic representation of a system that uses four symbol shapes to illustrate how the data flows through interconnected processes [3]. Some purposes of the use of DFD are to illustrate the flow of data within the system, to document the boundaries or scope of the visual system, to show the flow of data between a systems with other systems, and to support communication between system analysis with the users.

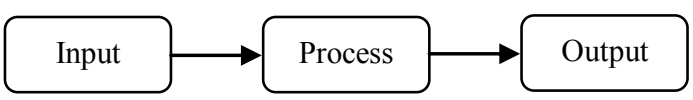

Figure 1. Relationship between elements in the system.

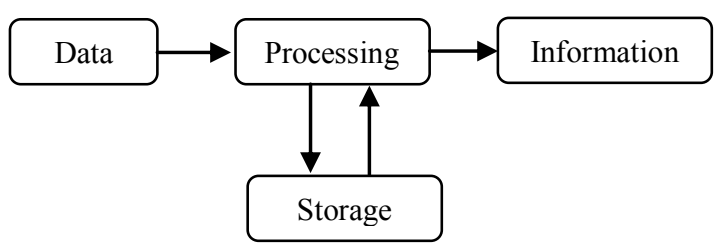

Figure 2. Relationship between data and information.

There are four symbol shapes are used to draw a DFD. These symbol shapes represent objects or processes contained within the system to be modeled. Symbols are used to draw a DFD can be seen in table I.

Information system is a subsystem within the organization that gathered the all needs of daily processing to support managerial operations to provide the other systems with the information needed to make decision [3]. Information system within organization provides information for all levels of the organizations whenever needed. These systems store, retrieve, modify, process and communicate information by using the information system or other system equipment.

TABLE I

DATA FLOW DIAGRAM NOTATION

\begin{tabular}{ll}
\multicolumn{1}{c}{ DATA FLOW DIAGRAM NOTATION } \\
\hline Symbol Shapes & \multicolumn{1}{c}{ Description } \\
& $\begin{array}{l}\text { External Entity } \\
\text { External entityis anentitythat exists } \\
\text { outsidethe system. }\end{array}$ \\
& $\begin{array}{l}\text { Process } \\
\text { The process is something that } \\
\text { transformsinputintooutput. }\end{array}$ \\
& $\begin{array}{l}\text { Datastore } \\
\text { Datastoreis a repository of data. } \\
\text { Data can be in form } \\
\text { ofdatabasefile,manual records,or } \\
\text { books. } \\
\text { Dataflow } \\
\text { Dataflowcanoccurbetweenprocess, } \\
\text { storage, andexternal entity. }\end{array}$ \\
\hline
\end{tabular}

The database is a collection of related data that are stored together on a storage medium in certain ways. It makes easy to be used or displayed again and can be optimal used by one or more application programs [2]. The essential elements of the database system are database as the main of database system, hardware to support data processing and humans who have an important role in that system.

Entity Relationship (ER) model is used to describing the relationship between data. ER model describes data as entity, relationships, and attributes. Schema of ER model can be drawn with graphic notation by using Entity Relationship Diagram (ERD). Some notation used in the ERD can be seen in table II [2].

After ERD finished, relational mapping is done. Relational mapping is used to map an ERD into the corresponding relational database schema. There is seven steps to perform relational mapping [2]. First, foreach strong entity type $\mathrm{E}$ in the ER schema, create a relation $\mathrm{R}$ that includes all the simple attributes of $\mathrm{E}$.

Second, for each weak entity type $\mathrm{W}$ in the ER schema with owner entity type E, create a relation $\mathrm{R}$, and include all simple attributes of $\mathrm{W}$ as attributes of $\mathrm{R}$.

In addition, include as foreign key attributes of R the primary key attribute (s) of the relations (s) that correspond to the owner of entity type. The primary key of $\mathrm{R}$ is the combination of the primary key (s) of the owner (s) and the partial key of the weak entity type W, if any. 
TABLE II

ENTITY RELATIONSHIP DIAGRAM NOTATION

Entity
Entityis an object that can be distinguishedbyitsattributes. An entity may be an object with a physical
existence or it may be an object with conceptual existence.

TABLE III

THE PROBLEMS OF CONSULTATION PROCESS IN INFORMATICS ENGINEERING DEPARTMENT OF UNIVERSITY ' $X$ '

\begin{tabular}{|c|c|}
\hline Lecturers' Problems & Students' Problems \\
\hline $\begin{array}{l}\text { 1. There was no notification if the lecturer made overlapping } \\
\text { schedule. } \\
\text { 2. Lecturers needed an administrative staff to arrange queue of } \\
\text { consultation appointments. } \\
\text { 3. Lecturers must left their room and went to the student lounge } \\
\text { to call their students. } \\
\text { 4. Every lecturer must informed to the administrative staff the } \\
\text { consultation schedule, capacity of every consultation } \\
\text { schedule, and if he/she wanted to change his/her schedule. } \\
\text { 5. Lecturers could not know history of student's consultation } \\
\text { any time. } \\
\text { 6. It was difficult to know the student who active or inactive on } \\
\text { final project consultation. } \\
\text { 7. It was difficult to know name list of students who registered } \\
\text { for consultation. Appointments data were on the } \\
\text { administrative table in the student lounge. }\end{array}$ & $\begin{array}{l}\text { 1. The consultation appointments process was } \\
\text { inefficient. It needed a few steps and a lot of time. } \\
\text { 2. The consultation appointments was ineffective. The } \\
\text { students made consultation appointments with } \\
\text { lecturer undirectly but via administrative staff. } \\
\text { 3. It was difficult to know which number of queue that } \\
\text { was being served by the lecturers. } \\
\text { 4. It was difficult to know the change of consultation } \\
\text { schedule without came to administrative staff. }\end{array}$ \\
\hline
\end{tabular}

Third, for each binary one to one relationship type $\mathrm{R}$ in the ER schema, identify the relations $\mathrm{S}$ and $\mathrm{T}$ that correspond to the entity type participating in $\mathrm{R}$. Choose one of the relations $\mathrm{S}$, say and include as foreign key in $\mathrm{S}$ the primary key of $\mathrm{T}$. It is better to choose an entity type with total participation in $\mathrm{R}$ in the role of $\mathrm{S}$. Include all the simple attributes of the 1:1 relationship type $\mathrm{R}$ as attributes of S. Fourth, for each regular binary $1: N$ relationship type $\mathrm{R}$, identify the relation $\mathrm{S}$ that represent the participating entity type at the $\mathrm{N}$ side of the relationship type. Include as foreign key in $\mathrm{S}$ the primary key of the relation $\mathrm{T}$ that represents the entity type participating in R. Include all the simple attributes of the 1:N relationship type as attributes of S. Fifth, for each regular binary M:N relationship type $\mathrm{R}$, create a new relation $\mathrm{S}$ to represent $\mathrm{R}$.

Include as foreign key attributes in $\mathrm{S}$ the primary keys of the relations that represent the participating entity types; their combination will form the primary key of S. Also include any 
simple attributes of the M:N relationship type as attributes of S. Sixth, for each multivalued attribute $\mathrm{A}$, create a new relation $\mathrm{R}$. This relation $\mathrm{R}$ will include an attribute corresponding to $\mathrm{A}$, plus the primary key attribute $\mathrm{K}$ as the foreign key in $\mathrm{R}$. The primary key of $\mathrm{R}$ is the combination of $A$ and K. Seventh, for each n-ary relationship type $\mathrm{R}$, where $\mathrm{n}>2$, create a new relation $\mathrm{S}$ to represent $\mathrm{R}$. Include as foreign key attributes in $\mathrm{S}$ the primary keys of the relations that represent the participating entity types. Also include any simple attributes of the n-ary relationship type as attributes of $\mathrm{S}$. The primary key of $\mathrm{S}$ is usually a combination of all the foreign keys that reference the relations representing the participating entity types.

\section{Result and Analysis}

The analysis was done by spreading questionnaire and direct observation. Observation made on the consultation process of two lecturers with their students at Informatics Engineering department, University ' $\mathrm{X}$ '. While the questionnaire distributed to fifty students who were waiting for consultation. Table IIIshows the problems that have been discovered [5].

Analysis result was used to define the system needs. The system needs have been summarized are [5]the students can make consultation appointments with lecturer directly, the students can easily know a queue number being served and the schedule changes without they must come to administrative staff location, there was notification if the lecturer made overlapping schedule, the lecturers do not need toleave the lecturers' room to call the next student who will consult, the lecturers can easily announce the schedule consulting, the queue capacity, and changes in consultation schedule, the queue list will automatically change if there is a student who had been served, lecturers can easily know name list of students who registered for consultation and the history of student's consultation any time, and there is a list of students who reported active and inactive on final project consultation.

TABLE IV

VALIDATION RESULTS

\begin{tabular}{|c|c|c|}
\hline Measured Parameters & Before & After \\
\hline \multicolumn{3}{|l|}{ Students } \\
\hline It is easy to make consultation & Agree : 0 student & Agree : 27 students \\
\hline \multirow{2}{*}{$\begin{array}{l}\text { appointments with lecturers. } \\
\text { and }\end{array}$} & Skeptic : 0 student & Skeptic : 2 students \\
\hline & Disagree : 30 students & Disagree : 1 student \\
\hline $\begin{array}{l}\text { Consultation appointments can be } \\
\text { performed any time }\end{array}$ & Agree : 0 Skeptic : 0 Disagree : 30 & Agree : 22 Skeptic : 4 Disagree : 4 \\
\hline \multirow{6}{*}{$\begin{array}{l}\text { It is easy to know which number of } \\
\text { queue that was being served by the } \\
\text { lecturers. } \\
\text { It is easy to know the change of } \\
\text { consultation schedule. }\end{array}$} & Agree $: 2$ & Agree : 29 \\
\hline & Skeptic : 10 & Skeptic : 0 \\
\hline & Disagree : 18 & Disagree : 1 \\
\hline & Agree : 1 & Agree : 29 \\
\hline & Skeptic : 0 & Skeptic : 0 \\
\hline & Disagree : 29 & Disagree : 1 \\
\hline \multirow{3}{*}{$\begin{array}{l}\text { It is easy to cancel the consultation } \\
\text { appointments that have been } \\
\text { scheduled. }\end{array}$} & Agree : 28 & Agree : 30 \\
\hline & Skeptic : 0 & Skeptic: 0 \\
\hline & Disagree : 2 & Disagree : 0 \\
\hline \multicolumn{3}{|l|}{ Lecturers } \\
\hline One consultation schedule can be & Agree : 0 lecturer & Agree : 5 lecturers \\
\hline $\begin{array}{l}\text { avoided to be overlapping with other } \\
\text { consultation schedules. }\end{array}$ & Disagree : 5 lecturers & Disagree : 0 lecturer \\
\hline It is easy to announce consultation & Agree : 0 & Agree : 5 \\
\hline $\begin{array}{l}\text { schedules, to record implementation } \\
\text { consulting, and to change } \\
\text { consultation schedules. }\end{array}$ & Disagree : 5 & Disagree : 0 \\
\hline \multirow{2}{*}{$\begin{array}{l}\text { Provided reports help lecturers to } \\
\text { take an action or to make decision. }\end{array}$} & Agree : 0 & Agree : 5 \\
\hline & Disagree : 5 & Disagree : 0 \\
\hline \multicolumn{3}{|l|}{ Both of Lecturers and Students } \\
\hline Percentage satisfaction to the & Lecturers : 40 & Lecturers: 90 \\
\hline system. & Students : 20 & Students : 95 \\
\hline Percentage of easiness to use & Lecturers : - & Lecturers : 80 \\
\hline consultation software. & Students : - & Students : 85 \\
\hline \multicolumn{3}{|l|}{ Researchers } \\
\hline $\begin{array}{l}\text { Number of stages that are needed to } \\
\text { perform consultations. }\end{array}$ & $\begin{array}{l}9 \text { stages (lectures schedule consultation, } \\
\text { given to the administrative staffs, } \\
\text { announcedto the students, accepted } \\
\text { registration, registration list was given to the } \\
\text { lecturers, approve/disapprove, given the } \\
\text { result to the administrative staffs, announced } \\
\text { the result to the students, consultation }\end{array}$ & $\begin{array}{l}3 \text { steps (lectures schedule consultation, } \\
\text { approve/disapprove the consultation } \\
\text { requests, consultation. }\end{array}$ \\
\hline
\end{tabular}




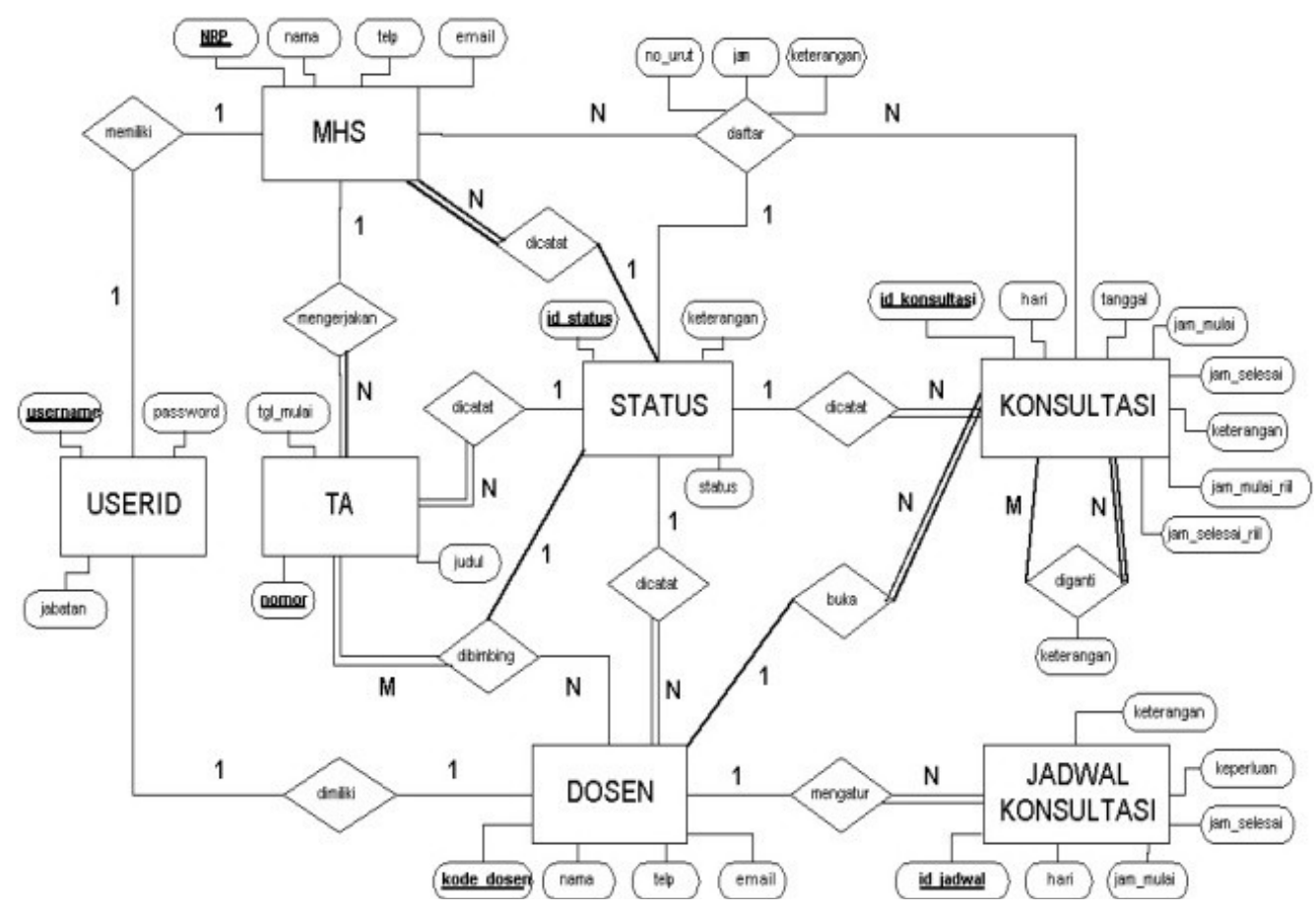

Figure 3. ERD of information system of consultation.

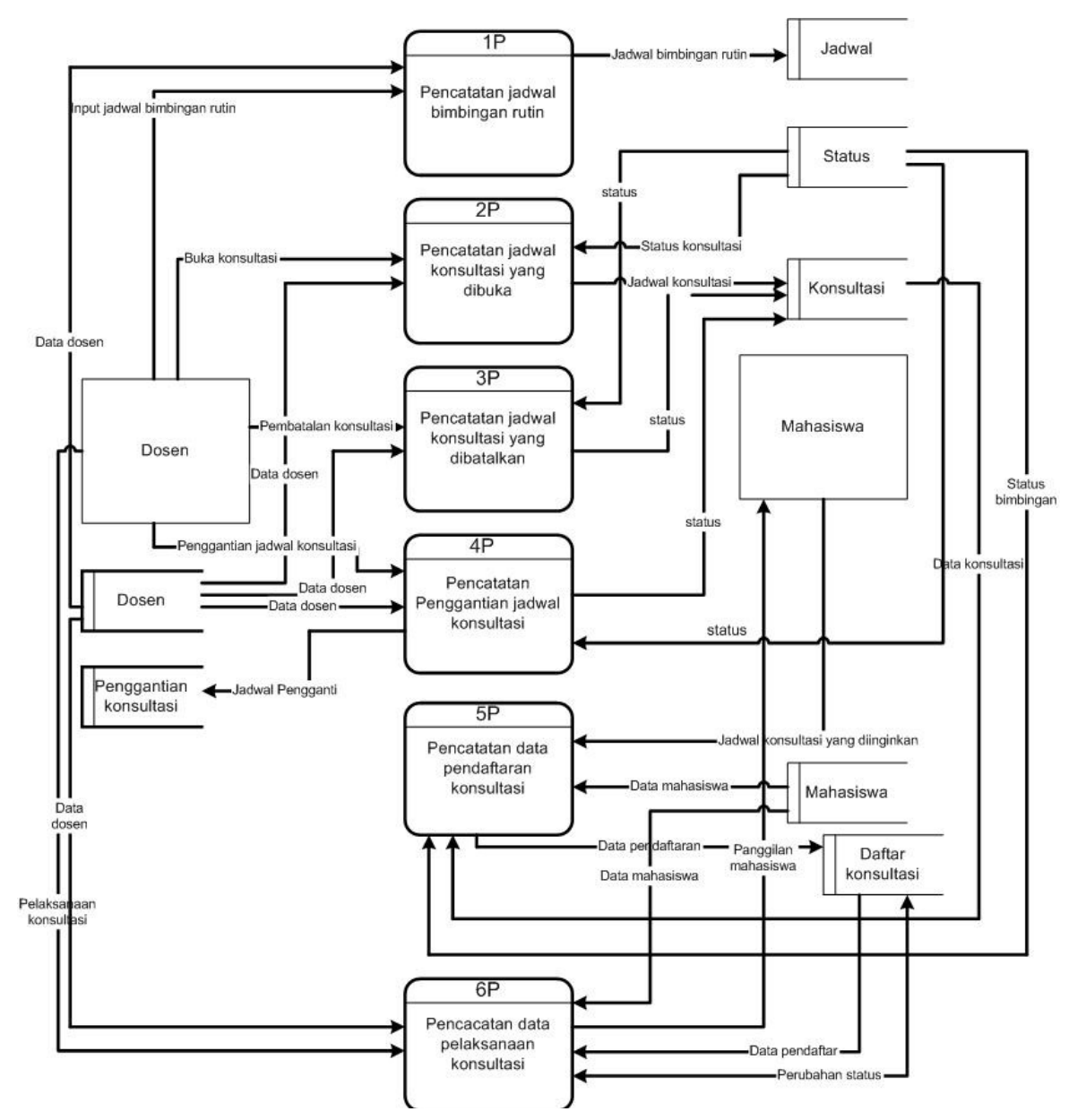

Figure 4. DFD level 1of consultation information system. 


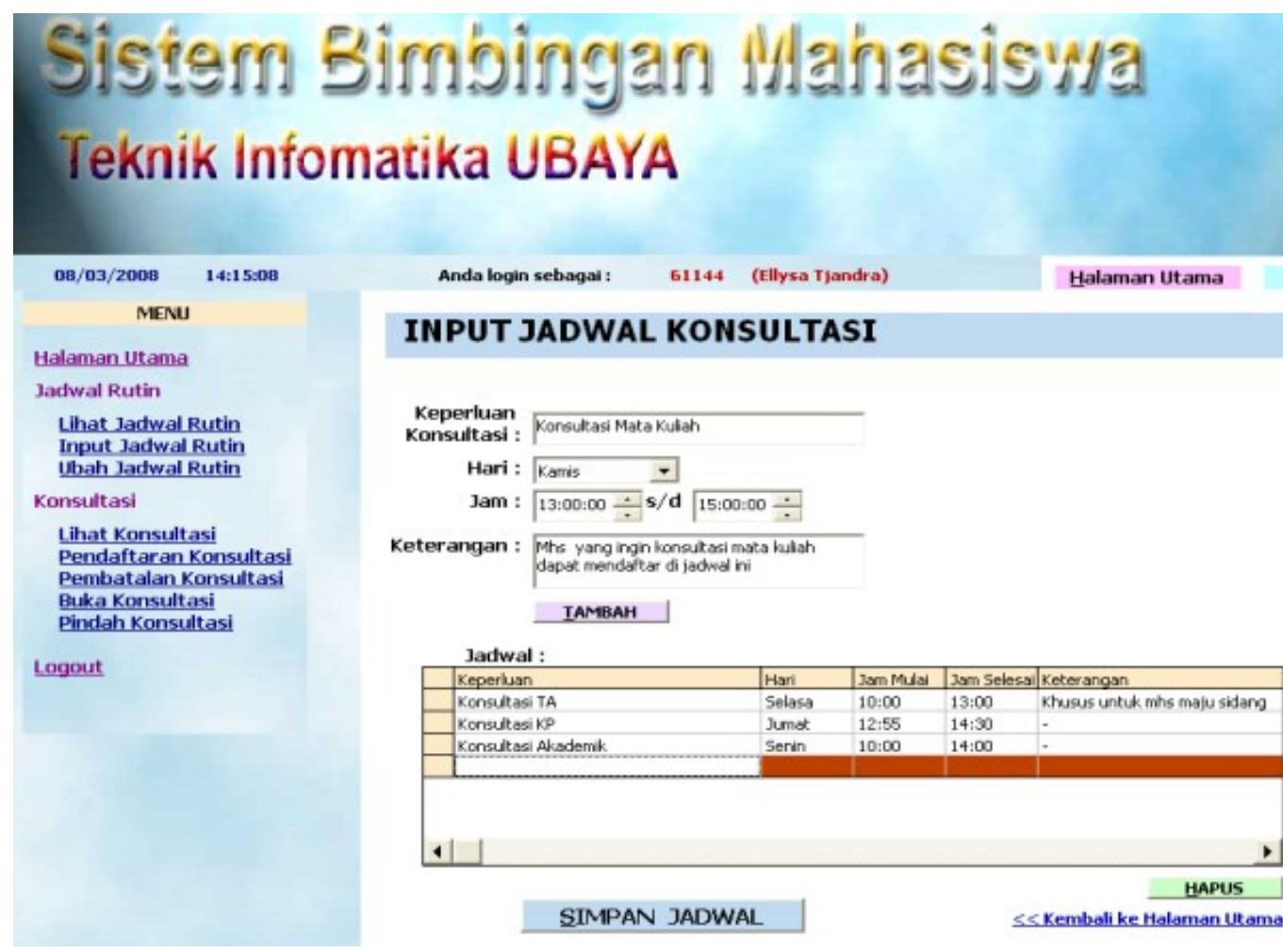

Figure 5. Form is used to record the schedule of lecturers' regular consultation.

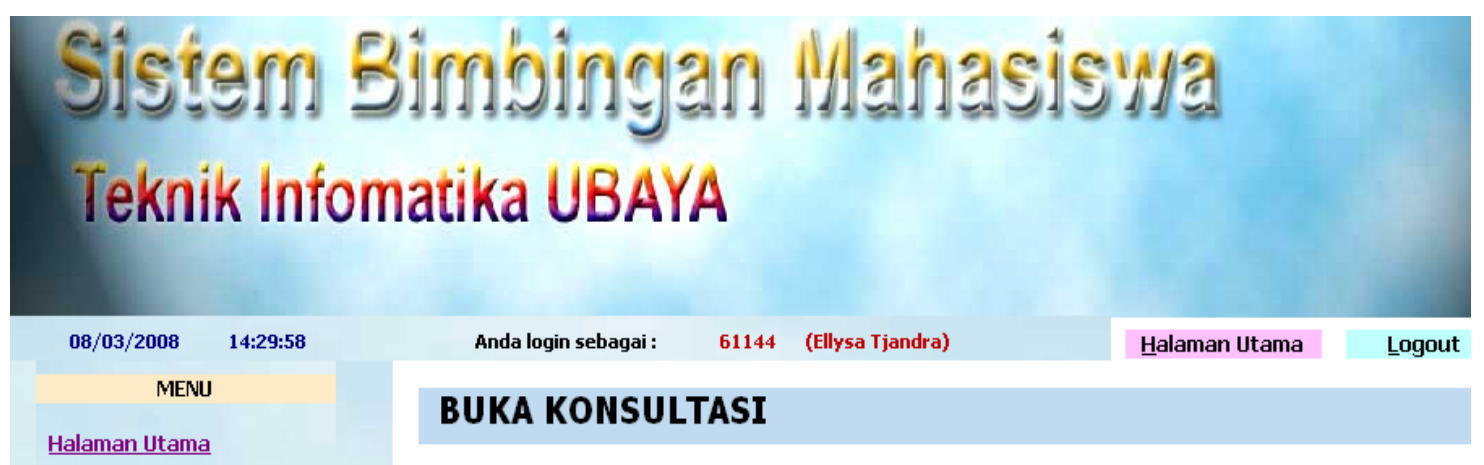

Jadwal Rutin

Lihat Jadwal Rutin

Input Jadwal Rutin

Ubah Jadwal Rutin

Konsultasi

Lihat Konsultasi

Pendaftaran Konsultasi

Pembatalan Konsultasi

Buka Konsultasi

Pindah Konsultasi

Logout

\section{BUKA KONSULTASI}
Tanggal : $11 / 03 / 2008 \quad \mathbf{}$

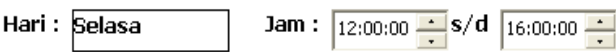

Keperluan
Konsultasi : Lainnya

Max Jumlah Mhs : $\quad 10$ *) Isi dengan nol jika jumlah mhs tidak dibatasi

Keterangan : Kelompok yang ingin konsultasi harus

membawa laporan gambaran sistem

SIMPAN

Figure 6. Form is used to record addition of lecturers' consultation schedule. 


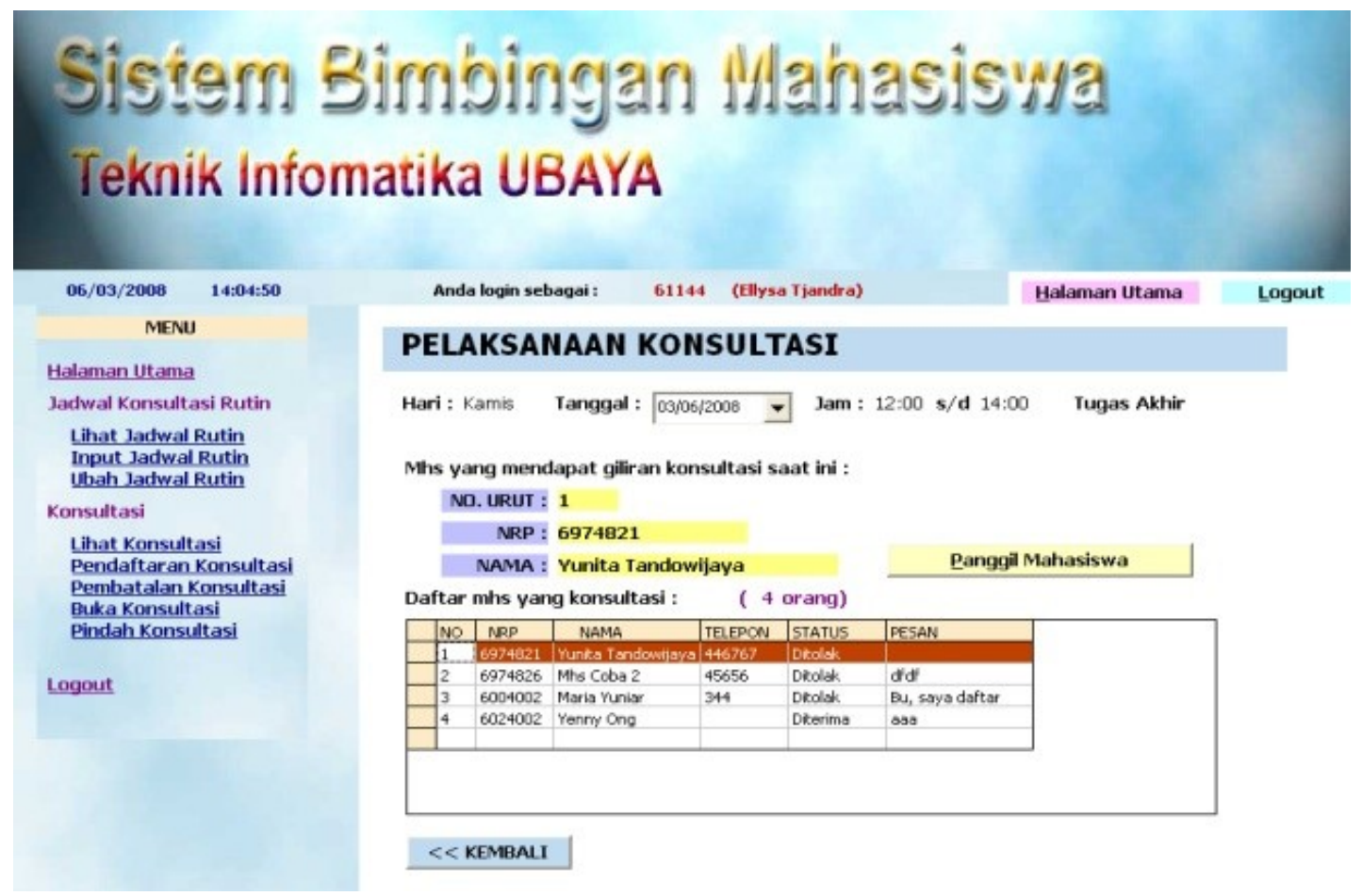

Figure 7. Form of implementation consulting.

The system needs would be used as a basis to design a new system. A new system that is proposed is Information System Software Based Intranet. Waterfall method is used to develop the new system [4]. There are four kinds of designs that were done to develop the new system: kind of users who use the system, data, process and user interface. The new system is made for two kinds of users: lecturer and student. Each kind of users have own accessibility. Data design is done by using the ERD. Result of data design can be seen in figure 3 [5]. Result of data design is used to support the processes in system. There are seven main processes : recording the schedule of regular consultation by lecturers, recording the addition of consultation schedule by lecturers (exclude of regular consultation schedule), cancelling a scheduled consultations, changing the schedule of consultations by lecturers, making a consultation registration by students, recording the implementation and results of consultation by lecturers, and generating reports. Data flow of the first six processes that occurs in the system can be seen in figure 4 [5].

The designs were implemented by using Microsoft Visual Basic version 6.0 and SQL Server for its database. Examples of the implementation can be seen in figure 5 until figure 7.

Figure 5 shows the form used to record the regular consultation schedule of Lecturers [5]. Figure 6 shows the form used to record the addition of lecturers' consultation schedule [5]. Example of implementation of the recording of the consultation process can be seen in figure 7 [5]. Figure 7 shows that lecturers do not need to go out into the student lounge to call the next student. Lecturers simply pressing the "Panggil Mahasiswa" button in the form "Implementation Consulting", then the computer will automatically send voice data to administrative staff's computer. Voice from speaker in the administrative staff's computer will call the student who had a turn.

The two tests were perform to ensure that the application has been running in accordance with system needs are verification and validation. Verification is performed by trying all of the functions provided by the application. After several improvements can be ascertained that all of the functions already running correctly on the application program. Validation is performed by applying the consultation program for the consultation process in Informatics Engineering department, University of ' $\mathrm{X}$ ' for one month. After one month, the performance of system was measured by spreading the questionnaires to the five lecturers and thirty students. Validation results can be seen in table IV.

The testing results showed that all the functions provided by the software are already running as it should. In addition, the questionnaire results indicate an improvement in efficiency, effectiveness, and satisfaction in the consultation process. Software is also easy to use 
but it is necessary to make more improvement. Some of the suggestions given by students during testing are to develop a web based software. It is expected so that consultation appointments can be performed and the required information can be obtained without limitation of time and place.

\section{Conclusion}

Consultation software provides various facilities to support consultationprocess. This facilities can reduce number of stages to perform consultations.So, it can increase efficiency and effectiveness, and improve satisfaction in consultation process between lecturers and students.

\section{Reference}

[1] J.A. O'Brien, Management Information
Systems, McGraw-Hill/Irwin, USA, p. 8, 2003.

[2] R. Elmasri \& S.B. Navathe, Fundamentals of Database System,3rd ed., Addison-Wesley, USA, p. 41, 2000.

[3] R. McLeod\&J.P. Schell,Management Information System, 10th ed.,Pearson International Edition, New Jersey, p. 14-194, 2007.

[4] R.S. Pressman,Software Engineering: A Practitoner's Approach, 5th ed., McGrawHill, Inc., USA., 2001.

[5] S. Limanto \& E. Tjandra, "Implementasi Sistem Bimbingan Dosen-Mahasiswa Berbasis Intranet", Research Report, Informatics Engineering, Universitas Surabaya, Surabaya, 2008. 